\title{
A new double-cube nitride complex containing titanium and potassium
}

\author{
Avelino Martín, Miguel Mena, Adrián Pérez-Redondo and Carlos Yélamos
}

Acta Cryst. (2011). C67, m157-m159

Copyright (C) International Union of Crystallography

Author(s) of this paper may load this reprint on their own web site or institutional repository provided that this cover page is retained. Republication of this article or its storage in electronic databases other than as specified above is not permitted without prior permission in writing from the IUCr.

For further information see http://journals.iucr.org/services/authorrights.html

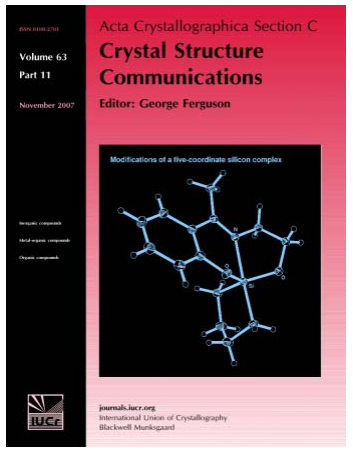

Acta Crystallographica Section C: Crystal Structure Communications specializes in the rapid dissemination of high-quality studies of crystal and molecular structures of interest in fields such as chemistry, biochemistry, mineralogy, pharmacology, physics and materials science. The numerical and text descriptions of each structure are submitted to the journal electronically as a Crystallographic Information File (CIF) and are checked and typeset automatically prior to peer review. The journal is well known for its high standards of structural reliability and presentation. Section $C$ publishes approximately 1000 structures per year; readers have access to an archive that includes high-quality structural data for over 10000 compounds.

\section{Crystallography Journals Online is available from journals.iucr.org}


Acta Crystallographica Section C

Crystal Structure

Communications

ISSN 0108-2701

\section{A new double-cube nitride complex containing titanium and potassium}

\section{Avelino Martín, Miguel Mena, Adrián Pérez-Redondo* and Carlos Yélamos}

Departamento de Química Inorgánica, Universidad de Alcalá, Campus Universitario, ES28871 Alcalá de Henares, Madrid, Spain

Correspondence e-mail: adrian.perez@uah.es

Received 23 February 2011

Accepted 5 April 2011

Online 28 April 2011

The reaction of the imide-nitride complex $\left[\left\{\mathrm{Ti}\left(\eta^{5}-\mathrm{C}_{5} \mathrm{Me}_{5}\right)\right.\right.$ $\left.(\mu-\mathrm{NH})\}_{3}\left(\mu_{3}-\mathrm{N}\right)\right]$ with potassium iodide in pyridine at room temperature affords the adduct di- $\mu$-iodido- $1: 1^{\prime} \kappa^{4} I$-bis $\left\{\right.$ tri- $\mu_{3^{-}}$ imido- $1: 2: 3 \kappa^{3} N ; 1: 2: 4 \kappa^{3} N ; 1: 3: 4 \kappa^{3} N$ - $\mu_{3}$-nitrido-2:3:4 $\kappa^{3} N$-tris$\left[2,3,4\left(\eta^{5}\right)\right.$-pentamethylcyclopentadienyl $]($ pyridine- $1 \kappa N)$-tetrahedro-potassiumtrititanium(IV)\}, $\left[\mathrm{K}_{2} \mathrm{Ti}_{6}\left(\mathrm{C}_{10} \mathrm{H}_{15}\right)_{6} \mathrm{I}_{2} \mathrm{~N}_{2}(\mathrm{NH})_{6}\right.$ $\left.\left(\mathrm{C}_{5} \mathrm{H}_{5} \mathrm{~N}\right)_{2}\right]$ or $\left[\left(\mathrm{C}_{5} \mathrm{H}_{5} \mathrm{~N}\right)(\mu-\mathrm{I}) \mathrm{K}\left\{\left(\mu_{3}-\mathrm{NH}\right)_{3} \mathrm{Ti}_{3}\left(\eta^{5}-\mathrm{C}_{5} \mathrm{Me}_{5}\right)_{3}\left(\mu_{3}-\mathrm{N}\right)\right\}\right]_{2}$. The crystal structure contains two $\left[\mathrm{KTi}_{3} \mathrm{~N}_{4}\right]$ cube-type units held together by two bridging I atoms. There is a centre of inversion located in the middle of this unprecedented discrete $\mathrm{K}_{2} \mathrm{I}_{2}$ unit. The geometry around $\mathrm{K}$ is best described as distorted trigonal prismatic, with three imide groups, two bridging I atoms and one pyridine ligand.

\section{Comment}

Polynuclear transition metal nitride complexes exhibit singular structures. These compounds might be of interest as building blocks in the synthesis of metal nitride materials (Oyama, 1996) or as intermediates in dinitrogen fixation and activation processes (see, for example, Fryzuk \& Johnson, 2000; Himmel \& Reiher, 2006; Kozak \& Mountford, 2004). However, a review of the literature reveals the lack of a systematic synthetic method for the preparation of these polynuclear complexes (Abarca et al., 2003; Dehnicke \& Strähle, 1992). In this context, the titanium imide-nitride compound $\left[\left\{\mathrm{Ti}\left(\eta^{5}-\mathrm{C}_{5} \mathrm{Me}_{5}\right)(\mu-\mathrm{NH})\right\}_{3}\left(\mu_{3}-\mathrm{N}\right)\right]$, (I) (Abarca et al., 2000; Roesky et al., 1989), is able to incorporate metal centres, and we have extensively investigated the rational synthesis of a series of heterometallic nitride complexes with cube-type structures. In particular, ligand (I) entraps alkali metal halides to give stable molecular adducts of the type $\left[X M\left\{\left(\mu_{3^{-}}\right.\right.\right.$ $\left.\left.\mathrm{NH})_{3} \mathrm{Ti}_{3}\left(\eta^{5}-\mathrm{C}_{5} \mathrm{Me}_{5}\right)_{3}\left(\mu_{3}-\mathrm{N}\right)\right\}\right](M=\mathrm{Li}$ and $X=\mathrm{Br}, \mathrm{I} ; M=\mathrm{Na}$ and $X=\mathrm{I}$ ) (García-Castro et al., 2005). However, the analogous treatment of (I) with amides of group 1 elements affords edge-linked $\left[M\left(\mu_{4}-\mathrm{N}\right)\left(\mu_{3}-\mathrm{NH}\right)_{2}\left\{\mathrm{Ti}_{3}\left(\eta^{5}-\mathrm{C}_{5} \mathrm{Me}_{5}\right)_{3}\left(\mu_{3}-\mathrm{N}\right)\right\}\right]_{2}$ or corner-shared $\left[M\left(\mu_{3}-\mathrm{N}\right)\left(\mu_{3}-\mathrm{NH}\right)_{5}\left\{\mathrm{Ti}_{3}\left(\eta^{5}-\mathrm{C}_{5} \mathrm{Me}_{5}\right)_{3}\left(\mu_{3}-\mathrm{N}\right)\right\}_{2}\right]$ double-cube complexes, depending on the reagent ratio of (I) and the amide (viz. 1:1 or 2:1; Martín et al., 2004).

The reaction of these edge-linked double-cube derivatives with metal halides has been used to prepare new heterometallic nitride complexes (García-Castro et al., 2001). Over the course of these investigations, we attempted to synthesize a zinc double-cube compound by treatment of the potassium derivative with $\mathrm{ZnI}_{2}$ in pyridine. After three days at room temperature, yellow crystals of $\left[\left(\mathrm{C}_{5} \mathrm{H}_{5} \mathrm{~N}\right)(\mu-\mathrm{I}) \mathrm{K}\left\{\left(\mu_{3}-\mathrm{NH}\right)_{3^{-}}\right.\right.$ $\left.\left.\mathrm{Ti}_{3}\left(\eta^{5}-\mathrm{C}_{5} \mathrm{Me}_{5}\right)_{3}\left(\mu_{3}-\mathrm{N}\right)\right\}\right]_{2}$, (II), were obtained in $27 \%$ yield. These crystals had a hexagonal prism shape and were air sensitive. Complex (II) was characterized by X-ray crystal structure determination, IR spectroscopy and CHN microanalysis. Compound (II) is not soluble in pyridine- $d_{5}$, and decomposes in benzene- $d_{6}$ or chloroform- $d_{1}$ to afford the imide-nitride ligand (I), KI and pyridine, precluding its characterization by NMR spectroscopy. Furthermore, a rational synthesis by reaction of (I) with $\mathrm{KI}$ in pyridine gave compound (II) in $73 \%$ yield.

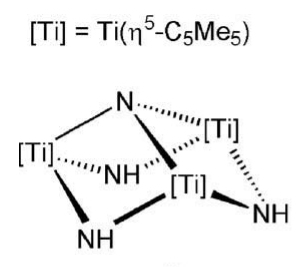

(I)

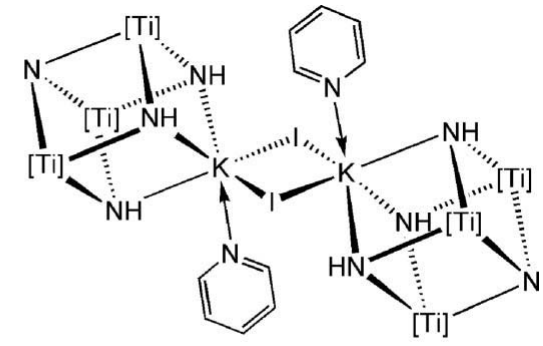

(II)
The structure of (II) (Fig. 1) contains two $\left[\mathrm{KTi}_{3} \mathrm{~N}_{4}\right]$ cubetype units linked by two bridging $\mathrm{I}$ atoms and related by a centre of inversion located in the middle of the planar $\mathrm{K}_{2} \mathrm{I}_{2}$ unit. The distance between the two K atoms is 4.629 (2) $\AA$, clearly shorter than the $\mathrm{K} \cdot \mathrm{K}$ lengths found for $\left[\mathrm{K}_{6} \mathrm{I}_{4}(\mathrm{dmp})_{8}\right]^{2+} \quad[\mathrm{dmp}$ is 2,9-dimethyl-1,10-phenanthroline; 4.960 (1) and 5.010 (1) $\AA$ ] , in which three $\mathrm{K}_{2} \mathrm{I}_{2}$ fragments are held together (Buttery et al., 2006). This phenanthroline derivative is the only compound in the Cambridge Structural Database (CSD, Version 5.32; Allen, 2002) containing I-bridged $\mathrm{K}_{2} \mathrm{I}_{2}$ units. Complexes with this type of unit, viz. $M_{2} \mathrm{I}_{2}$, are common for the lighter alkali metal iodide complexes (see, for example, Barrett et al., 2006; Fei et al., 2003; Herberich et al., 2005), but, to the best of our knowledge, there are no structural examples of compounds with discrete $\mathrm{K}_{2} \mathrm{I}_{2}$ units. The $\mathrm{K}-\mathrm{I}$ bond lengths in (II) [3.553 (1) and 3.605 (1) $\AA$ ] are slightly longer than the values found for the phenanthroline complex [3.303 (1)-3.581 (1) ̊]]. The $\mathrm{I}-\mathrm{K}-\mathrm{I}^{\mathrm{i}}$ and $\mathrm{K}-\mathrm{I}-\mathrm{K}^{\mathrm{i}}$ angles [symmetry code: (i) $-x+1,-y+1$, $-z+2]$ in our discrete unit [99.39 (3) and $80.61(3)^{\circ}$, respectively] are quite different to the values found for the polynuclear $\left[\mathrm{K}_{6} \mathrm{I}_{4}(\mathrm{dmp})_{8}\right]^{2+}$ cation described by Buttery et al. (2006) $\left[\mathrm{I}-\mathrm{K}-\mathrm{I}=85.78(3)-88.77(3)^{\circ}\right.$ and $\mathrm{K}-\mathrm{I}-\mathrm{K}=$ $\left.89.23(3)-97.39(3)^{\circ}\right]$.

The geometry around the potassium centre of (II) is best described as distorted trigonal prismatic, with the three imide groups of (I), two bridging iodide ligands and one $\mathrm{N}$ atom of 


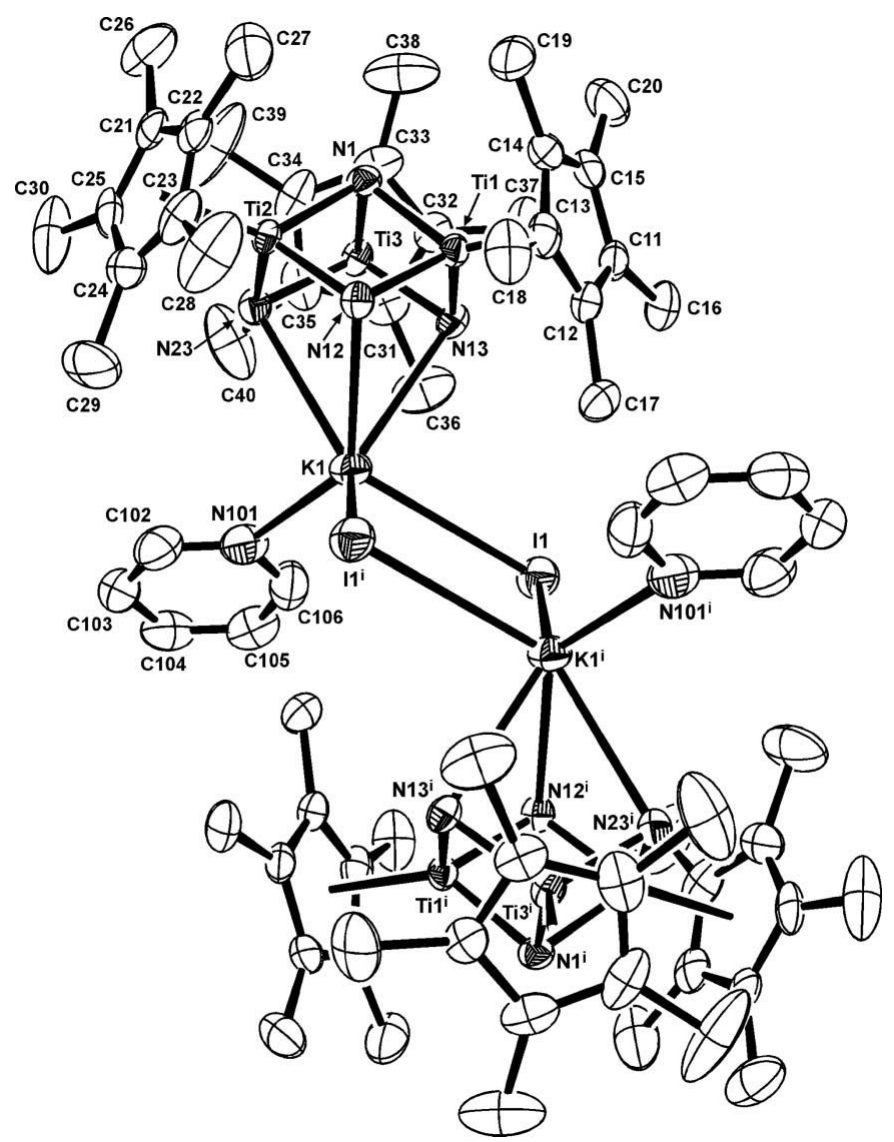

Figure 1

A perspective view of the molecule of (II), showing the atom-numbering scheme. Displacement ellipsoids are drawn at the $50 \%$ probability level. [Symmetry code: (i) $-x+1,-y+1,-z+2$.]

the pyridine group occupying the six coordination positions. The $\mathrm{K}-\mathrm{N}$ bond lengths [2.962 (3)-3.089 (3) $\mathrm{A}]$ are similar to those found for potassium complexes containing the neutral tridentate ligand $N, N, N^{\prime}, N^{\prime \prime}, N^{\prime \prime}$-pentamethyldiethylenetriamine [2.838 (3)-3.066 (5) А; Althaus et al., 1999; Craig et al., 1996; Fanjul et al., 2007]. Additionally, the $\mathrm{K}-\mathrm{N}$ bond distances for (II) are longer than those found for the cornershared double-cube complex $\left[\mathrm{K}\left(\mu_{3}-\mathrm{N}\right)\left(\mu_{3}-\mathrm{NH}\right)_{5}\left(\mathrm{Ti}_{3}-\right.\right.$ $\left.\left.\left(\eta^{5}-\mathrm{C}_{5} \mathrm{Me}_{5}\right)_{3}\left(\mu_{3}-\mathrm{N}\right)\right\}_{2}\right]$ [2.958 (2) Å; Martín et al., 2004], which presents intracube $\mathrm{N}-\mathrm{K}-\mathrm{N}$ angles [average $62.0(1)^{\circ}$ ] very similar to those in (II) [60.70 (9)-62.09 (9) $\left.{ }^{\circ}\right]$. The $\mathrm{N}_{\text {imide }}-\mathrm{K}-\mathrm{I}$ and $\mathrm{N}_{\text {imide }}-\mathrm{K}-\mathrm{N}_{\text {pyridine }}$ angles are in the range 74.18 (6)$138.2(1)^{\circ}$, whereas the $\mathrm{N}_{\text {pyridine }}-\mathrm{K}-\mathrm{I}$ angles are 92.89 (9) and $124.17(8)^{\circ}$. The $\mathrm{K}-\mathrm{N}_{\text {pyridine }}$ bond length [2.896 (4) $\AA$ ] compares well with those found in other potassium complexes containing a pyridine ligand [2.776 (3)-2.926 (2) $\AA$; see, for example, Boyle et al., 2003].

The $\mathrm{Ti}-\mathrm{N} 1$ and $\mathrm{Ti}-\mathrm{N}_{\text {imide }}$ distances in (II) [average 1.939 (4) and 1.946 (5) $\mathrm{A}$, respectively] are slightly longer than those determined for the free ligand $[1.913(8)$ and 1.929 (8) §; Roesky et al., 1989] and close to those found for the potassium corner-shared double cube [1.928(2) and 1.932 (6) ̊; Martín et al., 2004]. The average $\mathrm{N}_{\text {imide }}-\mathrm{Ti}-$ $\mathrm{N}_{\text {imide }}$ angle $\left[104.0(1)^{\circ}\right]$ is similar to that observed in the potassium double cube $\left[104.1(1)^{\circ}\right]$, whereas it is narrower than the same angle in the structure of (I) $\left[107.5(7)^{\circ}\right]$. The remainder of the parameters within the tridentate organometallic ligand are similar to those of these cited complexes.

\section{Experimental}

All manipulations were carried out under an argon atmosphere using Schlenk line or glove-box techniques. Pyridine was distilled from $\mathrm{CaH}_{2}$. Oven-dried glassware was repeatedly evacuated with a pumping system $\left(\mathrm{ca} 10^{-3}\right.$ Torr; 1 Torr $\left.=133.322 \mathrm{~Pa}\right)$ and subsequently filled with inert gas. Samples for IR spectroscopy were prepared as $\mathrm{KBr}$ pellets. Microanalysis $(\mathrm{CHN})$ was performed in a Leco CHNS932 microanalyser.

$\left[\left\{\mathrm{Ti}\left(\eta^{5}-\mathrm{C}_{5} \mathrm{Me}_{5}\right)(\mu-\mathrm{NH})\right\}_{3}\left(\mu_{3}-\mathrm{N}\right)\right], \quad(\mathrm{I}), \quad$ and $\quad\left[\mathrm{K}\left(\mu_{4}-\mathrm{N}\right)\left(\mu_{3}-\mathrm{NH}\right)_{2^{-}}\right.$ $\left.\left\{\mathrm{Ti}_{3}\left(\eta^{5}-\mathrm{C}_{5} \mathrm{Me}_{5}\right)_{3}\left(\mu_{3}-\mathrm{N}\right)\right\}\right]_{2}$ were prepared according to the methods of Abarca et al. (2000) and García-Castro et al. (2001), respectively. A pyridine solution $(15 \mathrm{ml})$ of $\left[\mathrm{K}\left(\mu_{4}-\mathrm{N}\right)\left(\mu_{3}-\mathrm{NH}\right)_{2}\left\{\mathrm{Ti}_{3}\left(\eta^{5}-\mathrm{C}_{5} \mathrm{Me}_{5}\right)_{3^{-}}\right.\right.$ $\left.\left(\mu_{3}-\mathrm{N}\right)\right]_{2}(0.20 \mathrm{~g}, 0.15 \mathrm{mmol})$ was carefully layered with a pyridine solution (5 ml) of $\mathrm{ZnI}_{2}$ (0.049 g, $0.15 \mathrm{mmol}$; Aldrich). The system was allowed to equilibrate for $3 \mathrm{~d}$ to afford yellow crystals of $\left[\left(\mathrm{C}_{5} \mathrm{H}_{5} \mathrm{~N}\right)\right.$ $\left.(\mu-\mathrm{I}) \mathrm{K}\left\{\left(\mu_{3}-\mathrm{NH}\right)_{3} \mathrm{Ti}_{3}\left(\eta^{5}-\mathrm{C}_{5} \mathrm{Me}_{5}\right)_{3}\left(\mu_{3}-\mathrm{N}\right)\right\}\right]_{2}$, (II) (yield $0.070 \mathrm{~g}, 27 \%$ ). The following rational method of synthesis may also be employed. A $100 \mathrm{ml}$ Schlenk flask was charged with (I) $(0.30 \mathrm{~g}, 0.49 \mathrm{mmol}), \mathrm{KI}$ $(0.080 \mathrm{~g}, 0.48 \mathrm{mmol} ; 98 \%$, Aldrich) and pyridine $(20 \mathrm{ml})$. The reaction mixture was stirred at room temperature for $20 \mathrm{~h}$. The resultant pale-yellow solid was isolated by filtration, washed with pyridine $(5 \mathrm{ml})$ and vacuum dried for $3 \mathrm{~h}$ to give (II) (yield $0.30 \mathrm{~g}, 73 \%$ ). IR $\left(\mathrm{KBr}, \tilde{v}, \mathrm{~cm}^{-1}\right): 3315(w), 2907(\mathrm{~m}), 2855(\mathrm{~m}), 1602(w), 1584(\mathrm{~m})$, $1484(w), 1438(m), 1376(m), 1218(w), 1147(w), 1069(w), 1029(m)$, $992(w), 758(v s), 713(s), 676(v s), 661(v s), 643(s), 606(m), 575(s)$, $472(m), 423(m)$. Analysis calculated for $\mathrm{C}_{70} \mathrm{H}_{106} \mathrm{I}_{2} \mathrm{~K}_{2} \mathrm{~N}_{10} \mathrm{Ti}_{6}: \mathrm{C} 49.26$, H 6.26, N 8.21\%; found: C 49.62, H 6.56, N 8.13\%.

\section{Crystal data}

$\left[\mathrm{K}_{2} \mathrm{Ti}_{6}\left(\mathrm{C}_{10} \mathrm{H}_{15}\right)_{6} \mathrm{I}_{2} \mathrm{~N}_{2}(\mathrm{NH})_{6^{-}}\right.$ $\left.\left(\mathrm{C}_{5} \mathrm{H}_{5} \mathrm{~N}\right)_{2}\right]$

$M_{r}=1707.05$

Triclinic, $P \overline{1}$

$a=11.298(2) \AA$

$b=11.346(2) \AA$

$c=18.391(3) \AA$

$\alpha=101.66(1)^{\circ}$

$$
\begin{aligned}
& \beta=93.46(1)^{\circ} \\
& \gamma=115.55(1)^{\circ} \\
& V=2053.8(6) \AA^{3} \\
& Z=1 \\
& \text { Mo } K \alpha \text { radiation } \\
& \mu=1.45 \mathrm{~mm}^{-1} \\
& T=200 \mathrm{~K} \\
& 0.32 \times 0.29 \times 0.23 \mathrm{~mm}
\end{aligned}
$$

\section{Data collection}

Nonius KappaCCD area-detector diffractometer

Absorption correction: multi-scan (Blessing, 1995)

$T_{\min }=0.594, T_{\max }=0.827$

34701 measured reflections 9150 independent reflections 6034 reflections with $I>2 \sigma(I)$ $R_{\text {int }}=0.045$

Refinement

$R\left[F^{2}>2 \sigma\left(F^{2}\right)\right]=0.047$

$w R\left(F^{2}\right)=0.119$

$S=0.98$

9150 reflections

433 parameters

$\mathrm{H}$ atoms bonded to $\mathrm{C}$ atoms were introduced at calculated positions and refined using a riding model, with $\mathrm{C}-\mathrm{H}=0.96 \AA$ and $U_{\text {iso }}(\mathrm{H})=1.5 U_{\text {eq }}(\mathrm{C})$ for the methyl groups of the cyclopentadienyl rings, and with $\mathrm{C}-\mathrm{H}=0.93 \AA$ and $U_{\text {iso }}(\mathrm{H})=1.2 U_{\text {eq }}(\mathrm{C})$ for the pyridine ligand. The $\mathrm{H}$ atoms of the imide groups were found in a 
Table 1

Selected geometric parameters $\left(\AA{ }^{\circ}\right)$.

\begin{tabular}{|c|c|c|c|}
\hline $\mathrm{K} 1-\mathrm{N} 12$ & $2.962(3)$ & Ti2-N12 & $1.936(3)$ \\
\hline $\mathrm{K} 1-\mathrm{N} 13$ & $2.986(3)$ & Ti2-N23 & $1.950(3)$ \\
\hline $\mathrm{K} 1-\mathrm{N} 23$ & 3.089 (3) & Ti3 - N13 & $1.947(3)$ \\
\hline $\mathrm{K} 1-\mathrm{N} 101$ & $2.896(4)$ & Ti3-N23 & 1.949 (3) \\
\hline $\mathrm{K} 1-\mathrm{I} 1$ & $3.553(1)$ & Ti1-N1 & $1.936(3)$ \\
\hline $\mathrm{K} 1-\mathrm{I} 1^{\mathrm{i}}$ & $3.605(1)$ & $\mathrm{Ti} 2-\mathrm{N} 1$ & $1.943(3)$ \\
\hline Ti1-N12 & $1.949(3)$ & $\mathrm{Ti3}-\mathrm{N} 1$ & 1.939 (3) \\
\hline Ti1 - N13 & $1.944(3)$ & & \\
\hline $\mathrm{N} 12-\mathrm{K} 1-\mathrm{N} 13$ & $62.09(9)$ & N1-Ti1-N12 & $85.8(1)$ \\
\hline $\mathrm{N} 12-\mathrm{K} 1-\mathrm{N} 23$ & $60.70(9)$ & N1-Ti1-N13 & 86.4 (1) \\
\hline $\mathrm{N} 13-\mathrm{K} 1-\mathrm{N} 23$ & $60.71(9)$ & $\mathrm{N} 1-\mathrm{Ti2}-\mathrm{N} 12$ & 86.0 (1) \\
\hline $\mathrm{N} 12-\mathrm{K} 1-\mathrm{I} 1$ & $123.11(6)$ & $\mathrm{N} 1-\mathrm{Ti} 2-\mathrm{N} 23$ & 85.9 (1) \\
\hline $\mathrm{N} 12-\mathrm{K} 1-\mathrm{I}^{\mathrm{i}}$ & $74.18(6)$ & $\mathrm{N} 1-\mathrm{Ti} 3-\mathrm{N} 13$ & $86.3(1)$ \\
\hline $\mathrm{N} 12-\mathrm{K} 1-\mathrm{N} 101$ & $138.2(1)$ & $\mathrm{N} 1-\mathrm{Ti} 3-\mathrm{N} 23$ & 86.0 (1) \\
\hline $\mathrm{N} 13-\mathrm{K} 1-\mathrm{I} 1$ & $79.45(7)$ & Ti1-N1-Ti2 & 94.0 (1) \\
\hline $\mathrm{N} 13-\mathrm{K} 1-\mathrm{I}^{\mathrm{i}}$ & $124.46(7)$ & Ti1-N1-Ti3 & 93.7 (1) \\
\hline $\mathrm{N} 13-\mathrm{K} 1-\mathrm{N} 101$ & $111.3(1)$ & Ti2-N1-Ti3 & 94.1 (1) \\
\hline $\mathrm{N} 23-\mathrm{K} 1-\mathrm{I} 1$ & $132.43(7)$ & Ti1-N12-Ti2 & $93.8(1)$ \\
\hline $\mathrm{N} 23-\mathrm{K} 1-\mathrm{I} 1^{\mathrm{i}}$ & $123.68(6)$ & Ti1-N12-K1 & $95.2(1)$ \\
\hline $\mathrm{N} 23-\mathrm{K} 1-\mathrm{N} 101$ & $79.8(1)$ & Ti2-N12-K1 & $98.3(1)$ \\
\hline N101-K1-I1 & $92.89(9)$ & Ti1-N13-Ti3 & $93.2(1)$ \\
\hline $\mathrm{N} 101-\mathrm{K} 1-\mathrm{I} 1^{\mathrm{i}}$ & $124.17(8)$ & Ti1-N13-K1 & 94.5 (1) \\
\hline $\mathrm{I} 1-\mathrm{K} 1-\mathrm{I} 1^{\mathrm{i}}$ & $99.39(3)$ & Ti3-N13-K1 & $97.9(1)$ \\
\hline $\mathrm{K} 1-\mathrm{I} 1-\mathrm{K} 1^{\mathrm{i}}$ & $80.61(3)$ & $\mathrm{Ti} 2-\mathrm{N} 23-\mathrm{Ti} 3$ & $93.6(1)$ \\
\hline N12-Ti1-N13 & $104.0(1)$ & Ti2-N23-K1 & 94.0 (1) \\
\hline $\mathrm{N} 12-\mathrm{Ti} 2-\mathrm{N} 23$ & $103.9(1)$ & $\mathrm{Ti3}-\mathrm{N} 23-\mathrm{K} 1$ & $94.6(1)$ \\
\hline $\mathrm{N} 13-\mathrm{Ti} 3-\mathrm{N} 23$ & $104.1(1)$ & & \\
\hline
\end{tabular}

Symmetry code: (i) $-x+1,-y+1,-z+2$.

difference Fourier map at the final stages of the refinement procedure and were refined freely.

Data collection: COLLECT (Nonius, 1998); cell refinement: $D I R A X / L S Q$ (Duisenberg, 1992); data reduction: EVALCCD (Duisenberg et al., 2003); program(s) used to solve structure: SHELXS97 (Sheldrick, 2008); program(s) used to refine structure: SHELXL97 (Sheldrick, 2008); molecular graphics: ORTEP-3 (Farrugia, 1997); software used to prepare material for publication: WinGX (Farrugia, 1999).

The authors are grateful to the Spanish MEC (grant No. CTQ2008-00061/BQU) and the Factoría de Cristalización (CONSOLIDER-INGENIO 2010 CSD2006-00015) for support of this research.
Supplementary data for this paper are available from the IUCr electronic archives (Reference: DT3001). Services for accessing these data are described at the back of the journal.

\section{References}

Abarca, A., Galakhov, M., Gracia, J., Martín, A., Mena, M., Poblet, J.-M., Sarasa, J. P. \& Yélamos, C. (2003). Chem. Eur. J. 9, 2337-2346.

Abarca, A., Gómez-Sal, P., Martín, A., Mena, M., Poblet, J.-M. \& Yélamos, C. (2000). Inorg. Chem. 39, 642-651.

Allen, F. H. (2002). Acta Cryst. B58, 380-388.

Althaus, H., Breunig, H. J., Probst, J., Rosler, R. \& Lork, E. (1999). J. Organomet. Chem. 585, 285-289.

Barrett, A. G. M., Gray, A. A., Hill, M. S., Hitchcock, P. B., Procopiou, P. A. \& White, A. J. P. (2006). Inorg. Chem. 45, 3352-3358.

Blessing, R. H. (1995). Acta Cryst. A51, 33-38.

Boyle, T. J., Andrews, N. L., Rodriguez, M. A., Campana, C. \& Yiu, T. (2003). Inorg. Chem. 42, 5357-5366.

Buttery, J. H. N., Effendy, Mutrofin, S., Plackett, N. C., Skelton, B. W., Whitaker, C. R. \& White, A. H. (2006). Z. Anorg. Allg. Chem. 632, 18091828.

Craig, F. J., Kennedy, A. R., Mulvey, R. E. \& Spicer, M. D. (1996). Chem. Commun. pp. 1951-1952.

Dehnicke, K. \& Strähle, J. (1992). Angew. Chem. Int. Ed. Engl. 31, 955-978.

Duisenberg, A. J. M. (1992). J. Appl. Cryst. 25, 92-96.

Duisenberg, A. J. M., Kroon-Batenburg, L. M. J. \& Schreurs, A. M. M. (2003). J. Appl. Cryst. 36, 220-229.

Fanjul, I., García, F., Kowenicki, R. A., Mosquera, M. E. G., McPartlin, M. \& Wright, D. S. (2007). Inorg. Chim. Acta, 360, 1266-1273.

Farrugia, L. J. (1997). J. Appl. Cryst. 30, 565.

Farrugia, L. J. (1999). J. Appl. Cryst. 32, 837-838.

Fei, Z., Scopelliti, R. \& Dyson, P. J. (2003). Inorg. Chem. 42, 2125-2130.

Fryzuk, M. D. \& Johnson, S. A. (2000). Coord. Chem. Rev. 200-202, 379409.

García-Castro, M., Gracia, J., Martín, A., Mena, M., Poblet, J.-M., Sarasa, J. P. \& Yélamos, C. (2005). Chem. Eur. J. 11, 1030-1041.

García-Castro, M., Martín, A., Mena, M., Pérez-Redondo, A. \& Yélamos, C. (2001). Chem. Eur. J. 7, 647-651.

Herberich, G. E., Englert, U. \& Wirth, T. (2005). Eur. J. Inorg. Chem. pp. 4924 4935.

Himmel, H.-J. \& Reiher, M. (2006). Angew. Chem. Int. Ed. 45, 6264-6288.

Kozak, C. M. \& Mountford, P. (2004). Angew. Chem. Int. Ed. 43, 1186-1189.

Martín, A., Mena, M., Pérez-Redondo, A. \& Yélamos, C. (2004). Inorg. Chem. 43, 2491-2498.

Nonius (1998). COLLECT. Nonius BV, Delft, The Netherlands.

Oyama, S. T. (1996). Editor. The Chemistry of Transition Metal Carbides and Nitrides. London: Blakie Academic and Professional.

Roesky, H. W., Bai, Y. \& Noltemeyer, M. (1989). Angew. Chem. Int. Ed. Engl. 28, 754-755.

Sheldrick, G. M. (2008). Acta Cryst. A64, 112-122. 